\title{
Perceptions of Early Childhood Student Teachers towards the Online Tutorial Courses at Universitas Terbuka (UT)
}

\author{
Titi Chandrawati \\ Early Childhood Study Program, Faculty of Education, Universitas Terbuka, Indonesia
}

Received December 24, 2019; Revised April 2, 2020; Accepted April 19, 2020

Copyright $\bigcirc 2020$ by authors, all rights reserved. Authors agree that this article remains permanently open access under the terms of the Creative Commons Attribution License 4.0 International License

\begin{abstract}
This article discusses how Universitas Terbuka (UT) has helped to change the way of teaching, especially early childhood education (ECE) student teachers learn in Indonesia, from being the passive students who were listening to the teacher in the class to be those who can learn actively and independently both face to face and online. The research was conducted in 2018 and 2019 by sending some open questions online and by interviewing some early childhood education (ECE) student teachers. The study also used the data from 2013 as comparison data. The data have been analyzed descriptively. The results showed that it is proven that UT has a role as an agent of change for the early childhood education (ECE) student teachers in Indonesia. By studying at UT, the ECE student teachers learn to explore actively and independently. Moreover, UT (Universitas Terbuka) has helped them to experience how to learn online. By participating in an online tutorial at UT, the ECE student teachers learn to use internet for learning, such as reading the learning materials online, by expressing their knowledge and posting their questions online. Thus, in UT, they learn to know and to learn how to be professional ECE student teachers.
\end{abstract}

Keywords Distance Education, Online Tutorial, Learning Online, the Changes in the way Students Learn, Universitas Terbuka

\section{Introduction}

Universitas Terbuka (UT) is entirely using distance education mode of learning. As a distance education university, UT implements an open distance learning system. The meaning of open in UT is that everyone has a high school, or its equivalent certificate can be UT students without any limitation on age, years of diplomas, of study, time registration, and the frequency of exams. The term distance education means that the learning process is not mainly done by face to face; instead, UT students can learn at a distance by any means. The students of UT have to learn the learning courses by reading the module. The module is the printed media and non-printed media, such as audio/ video, computer/ Internet, radio and television broadcasts. Theoretically, UT published and non-printed learning materials are intended to be learned independently. In addition to using learning materials provided by UT, students can also take the initiative to utilize the library (anywhere) or enroll in the face to face tutorial or via Internet, radio, television, and using other learning resources, such as programs audio/video [1].

The existence of UT with its Faculty of Education and Teacher Training (FKIP-UT) has helped the Indonesian government specifically in improving teachers' qualifications. FKIP-UT has helped many teachers get their S1 degree following the Indonesian government policy. The government believes that UT and its Faculty of Education and Teacher Training (FKIP) can help in preparing the future Indonesian generation to improve their skills and to utilize the industrial revolution 4.0 in their life. A teacher is a facilitator who drives the young generation to use the era of this industrial revolution 4.0 wisely. Thus, this paper aims to explain and discuss how UT has helped to change the way of teaching for Indonesian teachers, especially early childhood education (ECE) student teachers' learning.

In UT, ECE study program has 45 courses, and 26 of the courses are provided through face to face tutorials [2]. For the ECE courses that have no face-to-face tutorial, UT has provided an online learning tutorial as the learning support for the students who need that. However, participating in both face to face and online learning tutorials is not an obligation for UT students, since the tutorial in UT is 
provided as learning support for UT students who felt that they needed it. To provide better delivery of instruction, there is a need to understand how the students who engaged into online tutorials perceive the program. This study aimed to investigate the perceptions of the ECE students towards the online tutorials provided by UT.

\subsection{How UT Changes the Way of the ECE Students' Teachers Learn by Its Distance Education System}

Various reports from both national and international, both government and non-governmental organizations, show that the index of reading interest and literacy levels of the Indonesian people is still shallow. It means reading is not the Indonesian people's habit. However, by studying at UT, many ECE student teachers begin to get used to reading more, since studying at UT means that they have to read all the printed learning materials.

UT, with its distance education system, has used technology as the primary mean to improve UT's teaching and learning process and management. Even the ministry of research and technology and higher education explained that technology is the primary mean to enhance its teaching and learning process and also to help its management system [4].

In fact, in 2013, it was found through conversations with many Early Childhood Education students at UT that the students held the belief that participating in online learning was not exciting and was not useful to them. Hence, the students prefer to choose face to face tutorial. The fact is that not many Early Childhood Education students were joining the online tutorial [1].

Online learning nowadays is one of the trademarks of a distance education institution. As mentioned by Watts [5] in her dissertation, and also as described by Simonson and Schlosser that, distance education is "institution-based, formal education where the learning group is separated, and where interactive telecommunications systems are used to connect learners, resources, and instructors" [6].

To help the Indonesian teachers, especially the ECE student teachers to welcome and to adapt to the digital era, FKIP-UT has introduced and used the online tutorial as one of its academic services. To help the students to change to UT's online tutorial so, since 2018, UT has conducted a training called EKBJJ (Edukasi Keterampilan Belajar Jarak Jauh/ education for learning in the distance education system). In practice, UT's new students have been introduced with how to read faster, how to read effectively, time management, self-motivating, what and how to register to participate in an online tutorial.

\subsection{Online Learning in UT}

To accelerate the completion of the government mission, the top management of UT plans to use the online learning program as an additional form for its print-based instructional process [7]. The online learning program in UT, which was started in 1995, now seems to be widely used to serve its students, not only for its undergraduates but also for its master's degree program. This kind of teaching-learning process is a shift from only providing a face to face tutorial system. UT's online tutorial program is an example of UT's effort to adapt to technological developments and to meet the needs of students. By using the online tutorials, UT expects that the instructors can help and reach their students who live in areas that are difficult to achieve by face to face. Accordingly, UT then developed and implemented many online tutorials, which are supplemented as well with the printed learning materials. This online tutorial program is expected to maintain good interaction with students, and it is also developing an academic dialogue among students, tutors, and UT as the main curriculum providers.

\section{Method}

The research methods used are quantitative research methods. Quantitative research is simply a research that is presenting data using numbers, graphs, tables, and diagrams. The type of research used is survey research. Research surveys find out on a large number of people about how they behave, their opinions, what they say, or whether they do $[8,9]$.

Survey was used to explore how the UT students who are ECE student teachers perceive their experiences in learning online at UT. The research was conducted in 2018 and 2019 by simply answering using a rating scale. The information has been analyzed descriptively. From the questionnaire given to the 83 respondents who were UT's ECE student teachers who attended, survey was used by research to know and to understand how the respondents felt about learning at UT. Moreover, the researchers also tried to help the ECE student teachers learne about what is an online tutorial and experienced learning online

\section{Result and Discussion}

From the questionnaire given to the 83 respondents who were UT's ECE student teachers attended face to face tutorial in Jakarta, Semarang, and Surabaya, it was found that:

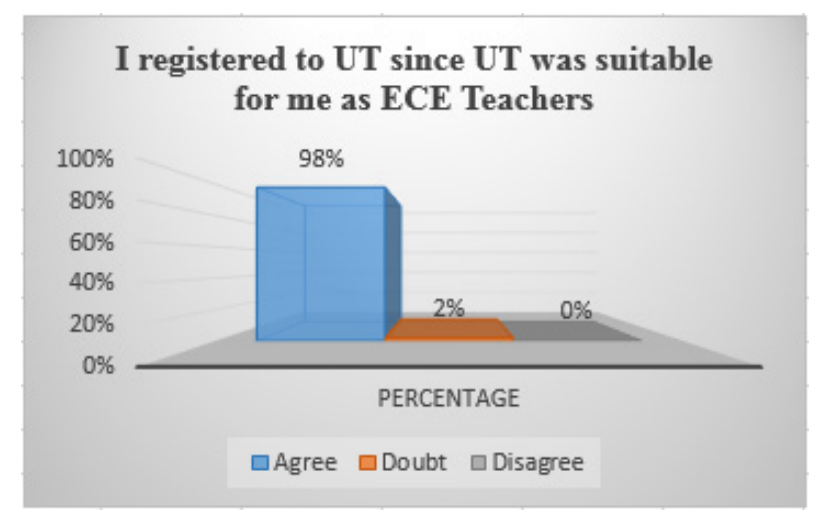

Figure 1. I registered to UT since I has known UT and the learning 
system

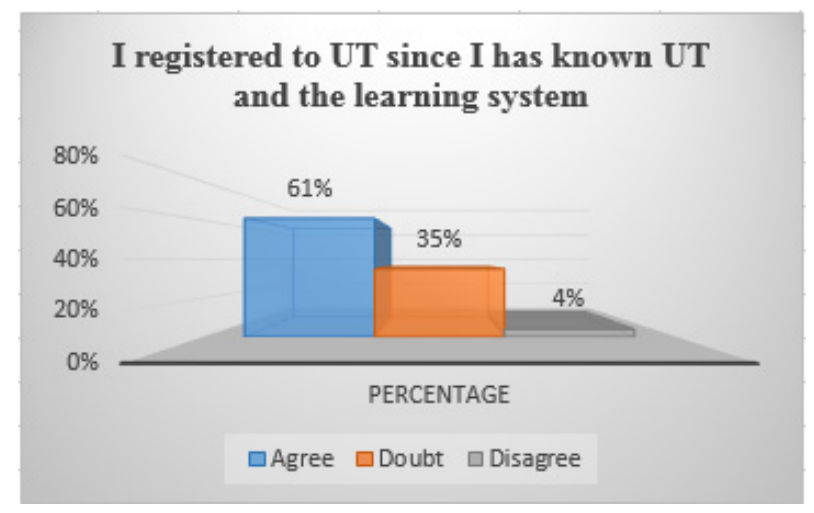

Figure 2. I registered to UT since I has known UT and the learning system

From Figure 1, it was shown that the ECE teachers registered to UT since UT was suitable for them, and the Figure 2, they understood about UT and the distance education learning system.

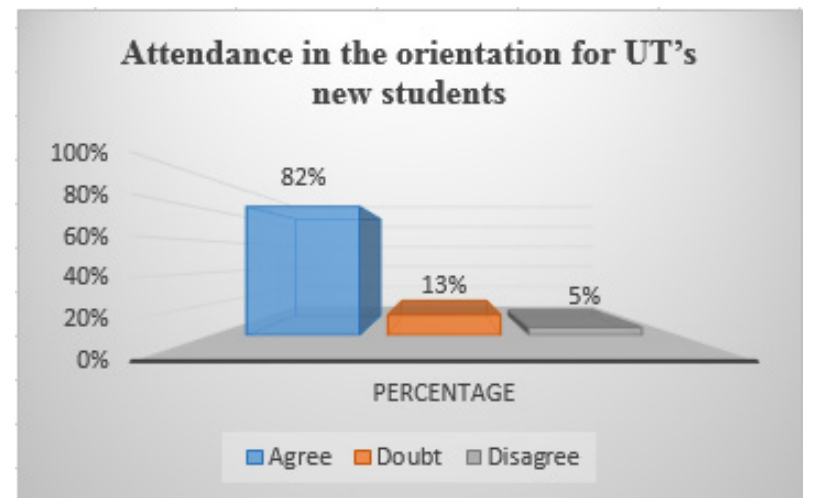

Figure 3. The Attendance in the orientation for UT's new students at the regional offices

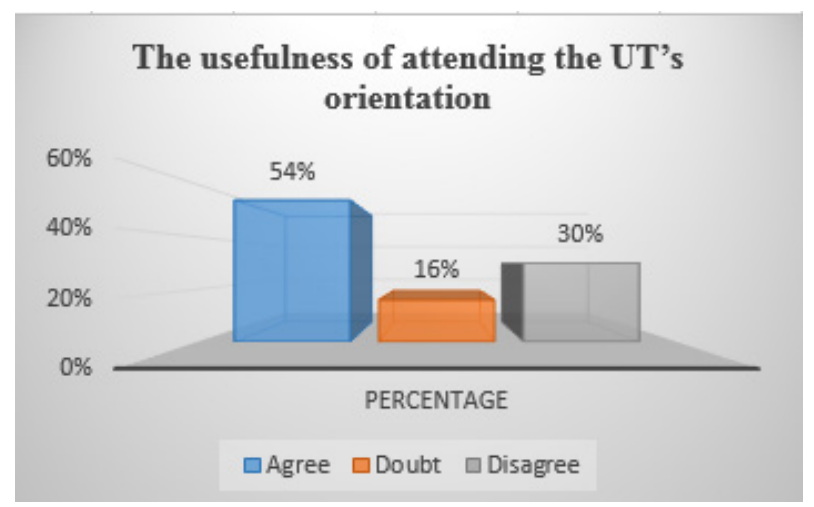

Figure 4. The Usefulness of attending the UT's orientation according to the respondents

From Figures 3 and 4, it was shown that the ECE student teachers felt that attending the orientation for the new students was good and helped them know more about UT and the distance education learning system.

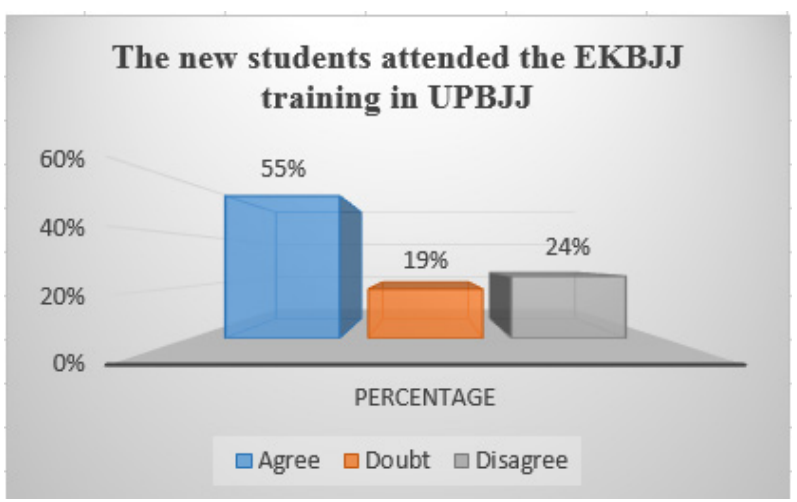

Figure 5. The Attendance of ECE student teachers who attended the EKBJJ training

From Figure 5, it can be shown that 55\% of the ECE new students participated in the training to help UT new students understand how to become UT students.

However, there were still ECE new student teachers who did not participate in an online tutorial, and they said that they did not know, as shown in Figure 6.

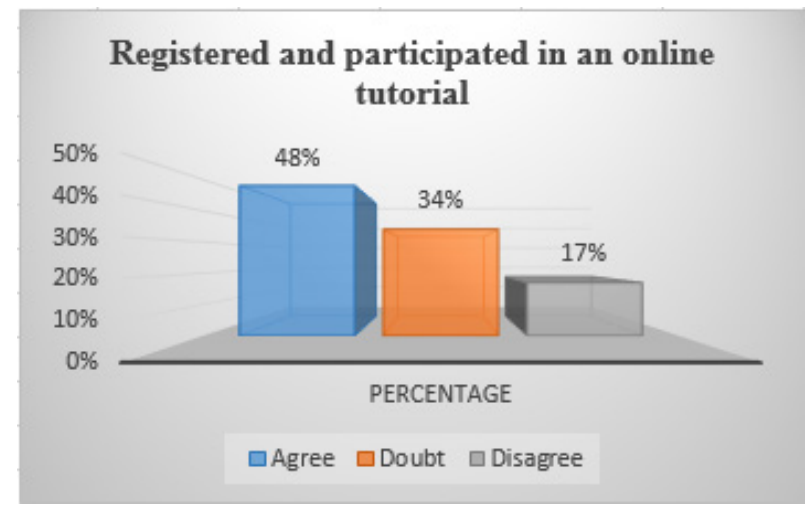

Figure 6. The descriptif of ECE student teachers did not registered and participated in an online tutorial

From Figure 6, it can be shown that the descriptif of ECE student teachers did not register and participate in UT's online tutorials because they did not know how to register in an online tutorial. Even though they have already attended the orientation and the training, they still did not understand how to use the online tutorial, as shown in Figure 7.

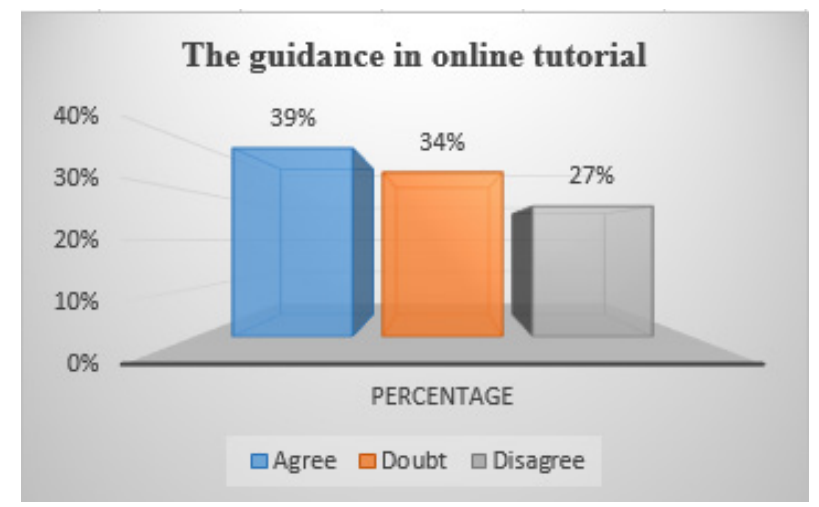

Figure 7. The guidance in the online tutorials even could not help me understand how to register and participate in an online tutorial 
Data from the online questionnaire revealed that the ECE student teachers who participated in an online tutorial felt that participating in online helped them with many useful things, as mentioned by the two selected participants:

"With this online tutorial, I can learn new things about the subjects I study, and the dialogues in this online tutorial are beneficial, and also I got a lot of knowledge from friends."

"Participating in an online tutorial is helping me understand this subject more deeply and helping me to know how to become a professional ECE student teachers"

"The benefits for me are significant to make me a professional early childhood education (ECE) teacher and form reading the learning material in the online tutorial I know steps on how to become a professional ECE student teachers"

"Studying at UT is very suitable for me, and I like to explore at UT online system like this because I live far from UT's regional centre in Palangkaraya"

"In the online tutorial, I learn from the explanation through the online initiation and from a discussion forum, so I can understand what the meaning and purpose of this course are."

"The advantage of this online tutorial is that we can hold opinions / discuss our views in our language and can see the opinions of other friends who are discussing and can work at any time. However, lack of this online tutorial is the students cannot directly ask the tutor in the discussion forum if something is not understood"

In the online tutorial, all of the participants should read the learning content in the initiation and answer or response to the $8^{\text {th }}$ topic discussions. It means that all of the online tutorial participants have to learn actively. Thus, if we compared the number of ECE student teachers who learn actively in their online tutorial, we can consider this fact. In 2013 the ECE student teachers who participated in the online tutorial from 100 students who registered, only 10 to 15 students wanted to actively participate in online discussions [1]. While in 2018 from 95 students per class who participated in the online tutorial 32 students actively discussed the topic discussion [10] and in 2019 from 50 students per class who participated in the online tutorial 33 students actively discussed the topic discussion [11]. In an online tutorial, the learning process has two ways; it means that the tutors try to have a dialogue with the students by doing discussions.

The results of this study supported the other research done by Chandrawati [10] in 2017/2018 that participating in online tutorials helped to make UT's ECE student teachers learn actively by discussing some topics, giving their opinions or perceptions towards the issues being discussed in the online tutorials. Further, the research by Chandrawati [10] also found that joining the online tutorial made the students get used to using computers and the internet. The results of this study showed that it is proven that UT has a role as an agent of change for the ECE student teachers in Indonesia since by studying at UT, the ECE student teachers learn to explore actively and independently. Moreover, UT has helped them to experience how to learn online. By participating in online tutorials at UT, the ECE student teachers learn to use the internet for learning, such as by reading the learning materials online, by expressing their knowledge and by posting their questions online. Thus, in UT, they learn to know and to learn how to be professional ECE student teachers. The findings also show that participating in an online tutorial can enhance students' involvement in their learning by stating their needs to others, sharing their experience, which is related with result finding by Ramadhan [12].

The results showed that dialogue in the online tutorials could help students to be engaged and connected with their tutor and their peers. The structure of the online tutorial and the discussion topic given by the tutor seemed to encourage the students to have dialogue among themselves.

\section{Conclusions}

This paper showed how UT with its system as an educational institution can help the Indonesian early childhood educators or the kindergarten teachers to prepare themselves in the era Revolution 4.0 and to increase their knowledge about being professional ECE student teachers by building UT's system in the online tutorial and by guiding and managing the UT students to experience learning online. Therefore, UT, as an institution, has successfully carried out its mission in widening access to higher education, for both practicing teachers and general society. By any means, UT represents one of the significant contributions to innovation in the modern Indonesian higher education system.

\section{REFERENCES}

[1] T. Chandrawati, "Understanding Dialogue in Distance Education: A Case study of the Indonesian Open University," dissertation, SFU, 2015.

[2] O. Darojat, et al., Basic Education Catalogue. Jakarta: Universitas Terbuka, 2009.

[3] Liputan6.com. (2017). Meningkatkan Budaya Baca dan Literasi Masyarakat Indonesia. Available: https://www.lip utan6.com/news/read/3203062/meningkatkan-budaya-baca -dan-literasi-masyarakat-indonesia?related $=$ dable\&utm_ex pid=.9Z4i5ypGQeGiS7w9arwTvQ.1\&utm_referrer=https $\% 3 \mathrm{~A} \% 2 \mathrm{~F} \% 2 \mathrm{Fwww}$.google.com $\% 2 \mathrm{~F}$

[4] O. Darojat, et. al., 34 tahun Universitas Terbuka: Cyber University Untuk Negeri. Jakarta: Universitas Terbuka, 
2018.

[5] L. K. Watts, The role of dialogue in distance education: $A$ qualitative study: The University of Nebraska-Lincoln, 2010.

[6] M. Simonson and L. A. Schlosser, Distance Education: Definition and Glossary of Terms, 3 ed. Charlotte, NC: Information Age Publishing, 2009.

[7] T. F. Luschei, S. Dimyati, and D. Padmo, "Maintaining e3learning while transitioning to online instruction: The case of the Open University of Indonesia," Distance Education, vol. 29, pp. 165-174, 2008.

[8] Setiawan, J. A., Suparno, Sahabuddin, C., Tasrif, \& Ramadhan, S. (2020). The Role of Parents on the Character Education of Kindergarten Children Aged 5-6 Years in Bima Universal Journal of Educational Research, 8(3), 779 - 784. doi: 10.13189/ujer.2020.080307.

[9] Wihardjo, R. S. D., Nurani, Y., \& Ramadhan, S. (2020). The Comparison between the Effectiveness of Guided Discovery Model and Inquiry Model for Early Childhood Education Students. International Journal of Innovation, Creativity and Change, 11(3), 409-418.

[10] T. Chandrawati, "How Online Tutorial Can Help Distance Education Students to be more Active in Their Learning," in 4th International Conference on Early Childhood Education. Semarang Early Childhood Research and Education Talks (SECRET 2018), 2018.

[11] T. Chandrawati, "a Report of dialogue in online tutorial," Universitas Terbuka, Jakarta, 2019.

[12] Ramadhan, S., Mardapi, D., Sahabuddin, C., \& Sumiharsono, R. (2019). The estimation of standard error measurement of physics final examination at senior high schools in bima regency indonesia. Universal Journal of Educational Research, 7(7), 1590-1594. https://doi.org/10.13189/ujer.2 019.070713 